\title{
Comparison of two birnavirus-rhabdovirus coinfections in fish cell lines
}

\author{
S. Rodriguez ${ }^{1}$, M. Alonso ${ }^{2}$, S. I. Pérez-Prieto ${ }^{1, *}$ \\ ${ }^{1}$ Departamento de Microbiología Molecular, Centro de Investigaciones Biológicas (CSIC), C/Ramiro de Maeztu 9, \\ 28040, Madrid, Spain \\ ${ }^{2}$ Department of Microbiology, Oregon State University, 220 Nash Hall, Corvallis 97330, Oregon, USA
}

\begin{abstract}
Aquabirnaviruses, such as the infectious pancreatic necrosis virus (IPNV), Novirhabdoviruses, such as the infectious hematopoiteic necrosis virus (IHNV) and the viral hemorrhagic septicemia virus (VHSV), cause considerable losses to the salmonid industry worldwide. Coinfections of 2 viruses have been described, but the interactions between rhabdoviruses and birnaviruses have not been examined closely. Using virus titration, flow cytometry and RT-PCR assays, we compared the effect of IPNV on the replication of IHNV and VHSV in tissue culture cells. RT-PCR assays indicated that simultaneous infection of IPNV with VHSV does not affect the replication of the rhabdovirus either in the first or successive passages; the infective titers were similar in single and double infections. In contrast, coinfection of IPNV with IHNV induced a fall in infectivity, with reduced expression of IHNV viral antigens in BF-2 cells from Lepomis macrochirus and a loss of $4.5 \log _{10}$ units of the infective titer after 3 successive passages. It was possible to stimulate BF-2 cells to produce significant interferon-like activity against IHNV but not against VHSV.
\end{abstract}

KEY WORDS: Infectious pancreatic necrosis virus · Infectious hematopoiteic necrosis virus · Viral hemorrhagic septicemia virus $\cdot$ Coinfections $\cdot$ Fish viruses

\section{INTRODUCTION}

Viral diseases have affected the development of aquaculture worldwide. Aquabirnaviruses, such as the infectious pancreatic necrosis virus (IPNV), and Novirhabdoviruses, such as the infectious haematopoiteic necrosis virus (IHNV) and the viral hemorrhagic septicemia virus (VHSV), have a severe impact on the industry's economy. All cause systemic infections with high mortality in young farmed rainbow trout Oncorhynchus mykiss and other salmonids, while the fish that survive a viral outbreak may, nevertheless, be asymptomatic carriers (Kim et al. 1999).

Originally enzootic on the west coast of North America, IHNV has been detected in Japan, Taiwan, China, Korea and Europe, where it has become established among several populations of reared rainbow trout (Winton 1991, LaPatra 1996). VHSV has historically affected farmed fishes in Europe (Wolf 1988), where until recently it was considered to cause a disease con- fined to freshwater salmonids. However, the presence of the virus in a wider range of marine fish species has been confirmed by numerous reports (Meyers et al. 1992, Mortensen et al. 1999).

IPNV is distributed worldwide and has also been isolated from other species of freshwater and marine fishes, molluscs and rotifers (Wolf 1988, Reno 1999, Rodriguez et al. 2003).

The broad distribution of IPNV, IHNV and VHSV among salmonids may favor the presence of several viruses in a single population. Some viral coinfections in fishes have been described: Schlotfeld \& Frost (1974) showed that rainbow trout can be infected with IPNV and VHSV; naturally occurring coinfections of IPNV and IHNV were reported in rainbow trout by Mulcahy \& Fryer (1976), LaPatra et al. (1993), Vilas et al. (1994) and Rodríguez et al. (1995)

Other coinfections in Atlantic salmon Salmo salar with IPNV and infectious salmon anemia virus (ISAV) have also been reported, with evidence that IPNV 
provides some protection against the secondary ISAV infection (Johansen \& Sommer 2001). Melby \& Falk (1995) infected an IPNV carrier stock of Atlantic salmon with tissue homogenates containing the infectious salmon anemia virus (ISA), and demonstrated that ISA infection did not activate the latent IPNV infections. More recently, Pakingking et al. (2003) explored experimental dual infections in flounder Paralichthys olivaceus with an aquabirnavirus and the VHSV on the one hand, and bacteria on the other. They concluded that the primary infection suppresses the secondary viral infection, but facilitates the bacterial infection. Further, the studies by Brudesth et al. (2002) on interactions between VHSV and IHNV during an experimental coinfection of rainbow trout demonstrated a reduced systemic distribution of IHNV.

All these reports indicate that interactions between viruses during simultaneous infections is as interesting a line of research in fishes, as it is proving to be in mammals. In previous studies we reported that IPNV interferes with the replication of IHNV in tissue culture cells and in fishes (Alonso et al. 1999a, 2003). The aim of the present study was to determine whether coinfections of VHSV or IHNV with IPNV present similar features; i.e. whether VHSV growth is affected in a similar way to that of IHNV and whether its infectivity is reduced. This is relevant to diagnoses, since the detection methods for viral coinfections would need to be improved, as rapid identification could prevent further spread. In addition, little is known about interactions between viruses during simultaneous infections in fishes. In this study, virus titration, flow cytometry and RT-PCR assays were performed to examine the effect of IPNV on the replication of IHNV and VHSV in fish cell lines.

\section{MATERIALS AND METHODS}

Cell lines and virus propagation. BF-2 from bluegill Lepomis macrochirus (ATCC CCL 91) and Epithelioma papulosum cyprini (EPC) cell lines were maintained in Leibovitz medium (L15, Gibco) supplemented with $100 \mathrm{U} \mathrm{ml}^{-1}$ penicillin, $100 \mu \mathrm{g} \mathrm{ml}^{-1}$ streptomycin, $2 \mathrm{mM}$ L-glutamine and $10 \%$ fetal bovine serum (FBS).

The Sp serotype of IPNV and the VR714 strain of IHNV were obtained from the American Type Culture Collection (ATCC VR714 and ATCC VR1318, respectively). VHSV Strain D was kindly provided by Dr. J. L. Barja, University of Santiago de Compostela. The IPNV-IHNV and IPNV-VHSV samples were a mix of IPNV with either IHNV or VHSV strains, and contained equal infectious titers of each virus. To prepare stocks, confluent BF-2 cells were infected at a multi- plicity of infection (MOI) of 0.01 with the IPNV-IHNV mix, the IPNV-VHSV mix or with IPNV, IHNV or VHSV reference viruses. After adsorption for $60 \mathrm{~min}$ at $15^{\circ} \mathrm{C}$, L15 supplemented with $2 \%$ FBS medium (L15 $2 \%$ ) was added to the monolayers. When a complete viral cytopathic effect (CPE) was evident, the tissueculture supernatant was harvested and centrifuged at $2500 \times g$ for $10 \mathrm{~min}$ at $4^{\circ} \mathrm{C}$ to remove cell debris. The $50 \%$ tissue culture infective dose $\left(\mathrm{TCID}_{50} \mathrm{ml}^{-1}\right)$ of the resulting supernatant was determined.

Virus titration. Subconfluent BF-2 cell monolayers growing in $25 \mathrm{~cm}^{2}$ flasks were inoculated with $2 \times$ $10^{5} \mathrm{TCID}_{50} \mathrm{ml}^{-1}$ of IPNV, IHNV or VHSV reference strains. We inoculated 2 additional flasks with mixed samples of either IPNV-IHNV or IPN-VHSV, respectively. The samples were diluted to contain the same proportion of the reference strains. The infected cultures were incubated at $15^{\circ} \mathrm{C}$ and samples of cells plus medium were processed at 48 and $120 \mathrm{~h}$ post infection (p.i.), by freezing and thawing the cells 3 times to determine the total yield (intracellular and extracellular) of the infectious virus. The viruses in coinfection were evaluated following a treatment that suppressed the activity of one virus without affecting the infectivity of the other, and the infective titers were determined. IPNV was neutralized by a 60 min incubation at $15^{\circ} \mathrm{C}$ with rabbit anti-IPNV serum. IHNV or VHSV were inactivated by the addition to the culture medium of an equal volume of chloroform for $1 \mathrm{~h}$, agitation and separation of the mixtures by centrifugation for $10 \mathrm{~min}$ at $4000 \times g$. The concentrations of infectious virus were estimated in BF-2 cells and EPC cells by the TCID 50 $\mathrm{ml}^{-1}$ assay.

Flow cytometry. BF-2 cell monolayers were processed for flow cytometry as described elsewhere (Pérez et al. 1994, Rodriguez et al. 2001). After the trypsin treatment, cells were fixed with $3.7 \%$ formaldehyde in phosphate-buffered saline (PBS) for $15 \mathrm{~min}$, washed twice in PBS, and permeabilized with $0.01 \%$ Triton X-100 in PBS for $1 \mathrm{~min}$. The pelleted cells were incubated for $30 \mathrm{~min}$ at room temperature with a 1:100 dilution of either IPNV polyclonal antiserum or VHSV polyclonal antiserum (Hill et al. 1981, Vilas et al. 1990) or with a 1:10 dilution of IHNV monoclonal antibody (MAb 1NDW14D, DiagXotics). After several washes in PBS supplemented with $2 \%$ FBS (PBS $2 \%$ ), the cells were incubated for $30 \mathrm{~min}$ at room temperature with goat anti-rabbit IgG-fluorescein isothiocyanate (FITC) conjugate or anti-mouse IgG-FITC conjugate (Sigma) and washed again. Finally, the fluorescence of the cell suspensions was determined using an EPICS XL flow cytometer equipped with an argon ion laser (Coulter). As controls, mock-infected cells were stained with the first and second antibodies; 5000 cells from each sample were analyzed. 
Oligonucleotide primers. The oligonucleotide primers were designed using the available sequences of the IPNV VP2, IHNV G or VHSV G genes (Koener et al. 1987, Thiéry et al. 1991, Pryde et al. 1993). To ensure specificity, the primers were compared with the sequences deposited in the GenBank using FASTA software; the primers G4/G5 were used to amplify a 1512 bp segment of the IHN viral cDNA encoding the G protein; the G4 primer (5'-ATGATCACCACTCCGCTCATT-3') was hybridized to Positions 1-21 (sense orientation) in the open reading frame (ORF) of the IHNV G gene; the G5 primer (5'-CCGGTTTGCCAGGTGATACAT-3') was 21 nucleotides long and hybridized to Positions 1492-1512 of the ORF (antisense orientation). The primers VG1/VGR (Bruchof et al. 1995) directed the synthesis of a 1522 bp segment of the VHSV viral cDNA encoding the G protein; the primer G1 (5'-ATGGAATGGAACACTTTTTTC-3') hybridized to Positions 1-21 (sense orientation) in the ORF of the G gene; the primer GR (TCAGACCGTCTGACTTCTGGA-3') hybridized to Positions 1505-1524 (antisense orientation) in the ORF of the G gene. The primers V1/V2 bracketed a 613 bp fragment within the VP2 coding region of the IPNV CDNA; the primer V1 (5'-GAACCCCCAGGACAAAGT-3') was 18 nucleotides long and hybridized to Positions 568-585 (sense orientation) and the primer V2 (5'-TGATTGGTCTGAGCACGC-3') hybridized to Positions 1164-1181 (antisense orientation) of the ORF (Pryde et al. 1993) The oligonucleotides were synthesized at the Laboratorio de Química de Proteínas, Centro de Investigaciones Biológicas (CSIC, Spain).

RNA extraction and cDNA synthesis. BF-2 cell monolayers were infected with an 0.01 MOI of IPNV, IHNV or VHSV reference strains or with either the IPNV-IHNV or IPNV-VHSV coinfected samples. After 2 to $3 \mathrm{~d}$, total RNA was extracted following the guanidinium thiocyanate-phenol-chloroform method (Chomczynski \& Sachi 1987). The RNA pellets were washed in $70 \%$ ethanol, dried, and resuspended in diethyl pyrocarbonate-treated water. Total RNA was incubated at $42^{\circ} \mathrm{C}$ for $1 \mathrm{~h}$ in a reverse transcription reaction mixture containing $50 \mathrm{mM}$ Tris- $\mathrm{HCl}(\mathrm{pH} 8.3), 50 \mathrm{mM}$ $\mathrm{KCl}, 10 \mathrm{mM} \mathrm{MgCl}, 80 \mathrm{mM}$ sodium pyrophosphate, $10 \mathrm{mM}$ of each dATP, dGTP and dTTP, and $5 \mathrm{mM} \mathrm{dCTP,}$ $20 \mathrm{U}$ of human placental ribonuclease inhibitor, $70 \mu \mathrm{M}$ of random hexanucleotide primer and $5 \mathrm{U}$ of reverse transcriptase. Following reverse transcription, the RNA-DNA hybrids were denatured at $100^{\circ} \mathrm{C}$ for $5 \mathrm{~min}$ and $2 \mu \mathrm{l}$ of the reaction mixture was used as a template for each of the subsequent PCR amplifications.

Polymerase chain reaction (PCR). Amplifications were performed in a $100 \mu \mathrm{l}$ reaction containing $2.5 \mathrm{mM}$ $\mathrm{MgCl}_{2}, 10 \mathrm{mM}$ Tris- $\mathrm{HCl}$ (pH 8), $50 \mathrm{mM} \mathrm{KCl}, 50 \mathrm{pmol}$ each of sense and antisense primers, $2 \mathrm{mM}$ dNTP mix,
$1 \mathrm{U}$ Taq-polymerase and $2 \mu \mathrm{l}$ of c-DNA. Amplifications were performed on an automatic thermocycler (Perkin Elmer Cetus) as follows: (1) 30 cycles of $1 \mathrm{~min}$ at $94^{\circ} \mathrm{C}$, $1.10 \mathrm{~min}$ at $55^{\circ} \mathrm{C}$ and $1 \mathrm{~min}$ at $72^{\circ} \mathrm{C}$ for the G4-G5 primers; (2) 35 cycles of $1 \mathrm{~min}$ at $94^{\circ} \mathrm{C}, 1 \mathrm{~min}$ at $53^{\circ} \mathrm{C}$ and 1 min at $72^{\circ} \mathrm{C}$ for the V1-V2 primers; (3) 25 cycles of $45 \mathrm{~s}$ at $94^{\circ} \mathrm{C}, 1 \mathrm{~min}$ at $55^{\circ} \mathrm{C}$, and $1.5 \mathrm{~min}$ at $72^{\circ} \mathrm{C}$ for the VG-VGR primers. The amplified products were analyzed by electrophoresis in $1.2 \%$ agarose gels stained with ethidium bromide.

Interference assay. The BF-2 cells were examined for their ability to induce anti-viral factors or interferon-like activity that could be secreted from the cells, stimulate new cell monolayers, and contribute to the loss of infectivity of the virus. The method used to assay BF-2 cell supernatants was adapted from that described by Jensen et al. (2002a). Briefly, cells growning in plastic flasks of $25 \mathrm{~cm}^{2}$ were left untreated or stimulated with $500 \mu$ polyinosinic:cytidylic acid (poly I:C, $\left.10 \mu \mathrm{g} \mathrm{ml}^{-1}\right)$ and $50 \mu \mathrm{l}$ of DEAE-dextran $(100 \mu \mathrm{g}$ $\mathrm{ml}^{-1}$ ) for $48 \mathrm{~h}$. Supernatants of the cultures were removed and used to stimulate subconfluent cell monolayers growing in 48-well plates. After $1 \mathrm{~h}$ adsorption, the medium was removed, the cells washed once in PBS, infected with IPNV, IHNV and VHSV (0.05 MOI and 4 wells per sample) and incubated at $15^{\circ} \mathrm{C}$. After $48 \mathrm{~h}$, pooled medium and cells from the 4 wells of each sample were harvested, frozen and thawed 3 times to disrupt the cells, and inoculated (serial decimal dilutions) in 96-well plates for viral titration.

\section{RESULTS}

\section{Viral replication}

The relative amounts of infectious particles of each of the viruses present in either the IPNV-IHNV or IPNV-VHSV mixed samples were evaluated at $48 \mathrm{~h}$ p.i. For IPNV-IHNV samples, titrations were also performed at $120 \mathrm{~h}$ p.i., as IHNV growth is slower. The IPNV and VHSV showed infective titers of $1 \times 10^{8}$ $\mathrm{TCID}_{50} \mathrm{ml}^{-1}$ as early as $48 \mathrm{~h}$ p.i., while at this time the IHNV displayed titers of $1 \times 10^{6} \mathrm{TCID}_{50} \mathrm{ml}^{-1}$ (Table $1 \mathrm{P}_{1}$ ). When BF-2 cells were infected with the IPNV- IHNV mixed sample, the infective titer of IHNV decreased by $2 \log _{10}$ units at $120 \mathrm{~h}$ p.i., compared to the IHNV in the single infection. No differences between the infective titers of IPNV were observed in BF-2 cells infected with IPNV in single or double infections with either IHNV or VHSV (IPNV infective titers were always around $1 \times 10^{8}$ ). The EPC cells did not support IPNV replication, which allowed us to observe both IHNV and VHSV replication. In these cells, IHNV and VHSV in coinfection 


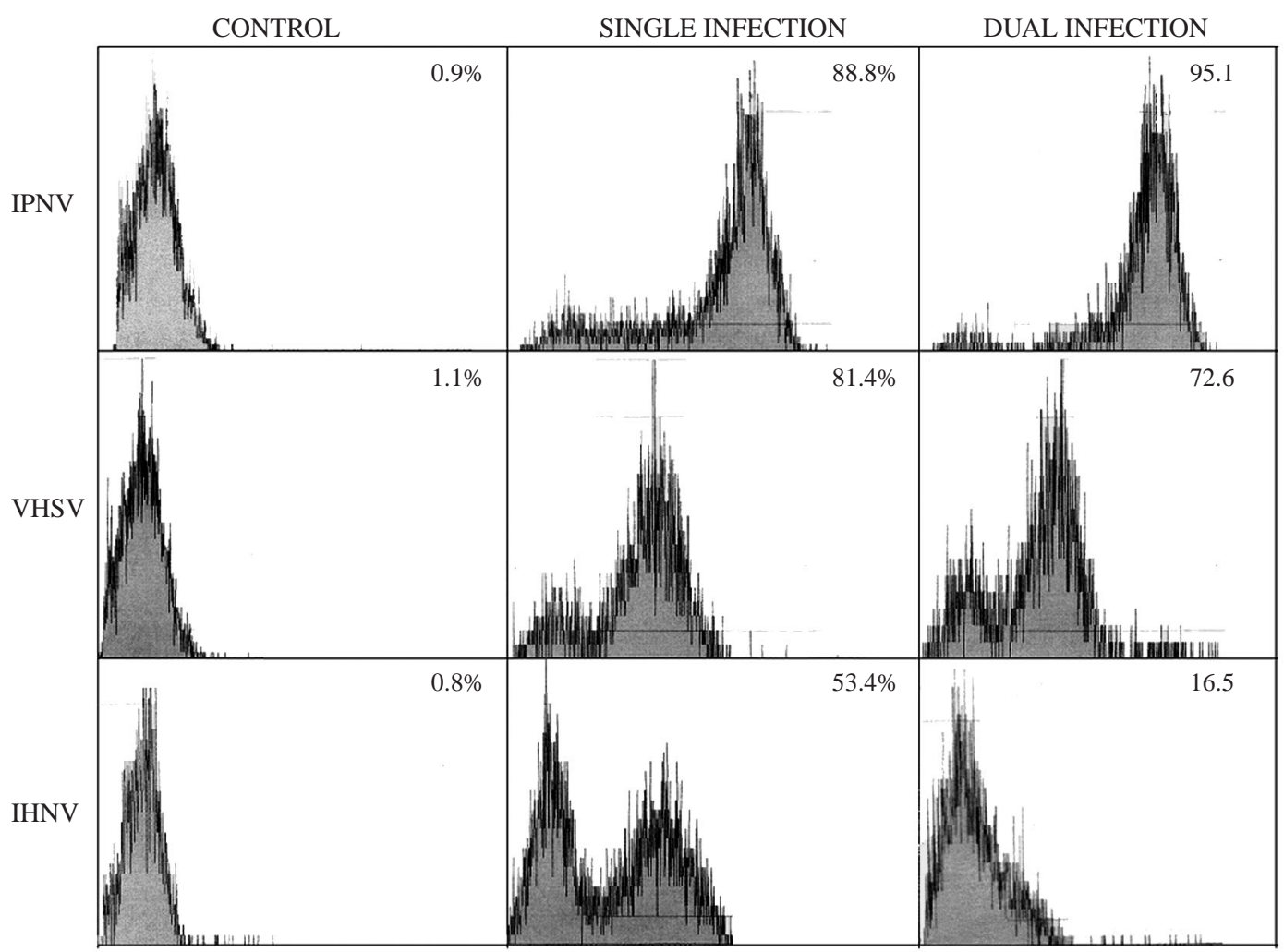

Fig. 1. Flow cytometry histograms for samples of BF-2 cells (from bluegill Lepomis macrochirus) infected singly with IPNV, VHSV or IHNV and with IPNV-VHSV or with IPNV-IHNV dual infections. ( $y$-axis: \% fluorescent cells; $x$-axis: intensity of fluorescence). Cells stained by indirect immunofluorescence at $48 \mathrm{~h}$ post-infection with polyclonal anti-IPNV anti-VHSV serum or IHNV monoclonal antibody and a commercial anti-species IgG-FITC conjugate. Background fluorescence measured by negative controls (mock-infected cells stained with corresponding reactives to each virus: control histograms; $5 \times 10^{3}$ cells per sample were analyzed. Dual infection panels represent percentages of cells expressing IPNV after coinfection with VHSV (upper histogram), percentages of cells expressing VHSV antigens after coinfection with IPNV (middle histogram) and the same for IHNV from a coinfection with IPNV (bottom histogram). The single infection column represents percentages of cells expressing indicated viral antigens, in conventional infections
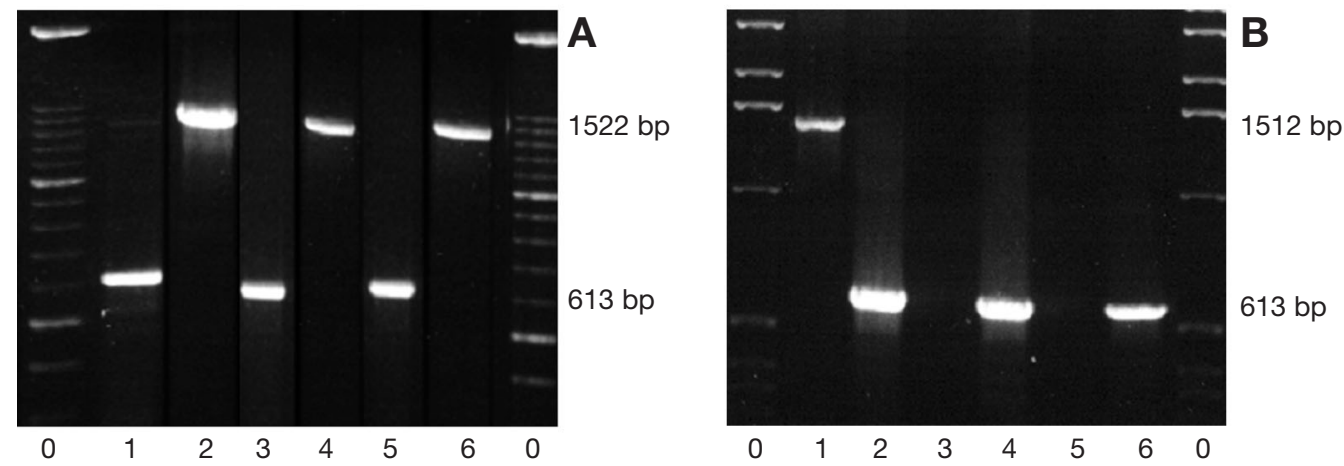

Fig. 2. Analysis of RT-PCR products from samples of experimental coinfections of IPNV with IHNV or VHSV. (A) RT-PCR amplification of IPNV-VP2 gene fragment (613 bp) and the VHSV-G gene fragment (1522 bp), from the IPNV-VHSV coinfection of BF-2 cells (from bluegill Lepomis macrochirus), at 3 successive passages. Lanes 1, 3, 5: PCR products from samples of the IPNV fraction of the coinfection IPNV-VHSV at the 1st, 2nd and 3rd passages, respectively; Lanes 2, 4, 6: PCR products from samples of the VHSV fraction of the coinfection IPNV-VHSV for the same passages. Lanes 0: XIV Boehringer size marker. (B) Same experiment as (A), but with the IPNV-IHNV coinfection. Lanes 1,3,5: PCR products from samples of the IHNV fraction at the 1st, 2nd and 3rd passages, respectively; Lanes 2,4,6: PCR products from samples of the IPNV fraction for same passages. Lanes 0: XIV Boehringer size marker 
protection against the tested viruses. The highest protection was observed against the IHNV, which exhibited differences of $2 \log _{10}$ in the infective titer compared to the untreated control. The VHSV was only slightly affected (0.5 $\log _{10}$ less infective titer), while no protection against the IPNV was detected.

\section{DISCUSSION}

This study has demonstrated that viral coinfection of IPNV with VHSV does not affect the replication of any of the viruses in BF-2 cells or EPC, while the coinfection of IPNV with IHNV in BF-2 cells induces a decrease in the infective titer of this rhabdovirus, and this is more evident after 3 passages.

It was possible to detect both IPNV and VHSV by RT-PCR at each of the 3 successive passages in coinfection, while IHNV was only detected at the first passage. In previous studies, we demonstrated that IPNV interferes with the growth of IHNV in tissue culture cells and in fishes (Alonso et al. 1999a, 2003). Successive passages of the coinfected sample led to a decrease in IHNV mRNA and the absence of the specific PCR product for IHNV, with a nested-PCR assay being required to amplify the IHNV (Alonso et al. 1999b). We demonstrated that IPNV also interferes with IHNV replication in vivo. Rainbow trout populations infected with the IPNV-IHNV.S46 coinfected sample showed $50 \%$ less mortality than fish infected with the reference viruses alone (Alonso et al. 2003).

Herein, we have shown that VHSV, in simultaneous infection with IPNV, infected BF-2 cells with similar titers to those for single infections. In addition, the number of cells expressing VHSV-viral antigens at $48 \mathrm{~h}$ p.i. was similar in a VHSV infection and an IPNVVHSV coinfection, as were the intensity and distribution of the fluorescence revealed by flow cytometry. An IPNV-IHNV coinfection decreases infectivity of the IHNV by $2 \log _{10}$ in this cell line at the first passage, and more than $4 \log _{10}$ after successive passages. Flow cytometry experiments showed that the number of cells expressing IHN viral antigens was 3.25-fold lower in a coinfection with IPNV than in a single infection. RT-PCR experiments confirmed this reduction.

The mechanisms of host-virus interaction are poorly understood in the case of rhabdovirus infection in fishes and there is little information indicating why IHNV and VHSV multiplication differ so markedly in the presence of IPNV. One explanation might be that the faster growing IPNV out-competes IHNV and replicates to a high titer, whereas IHNV replicates to a much lower titer. Thus, during passages, there is more IPNV, which again out-competes IHNV. As the VHSV replicates at a similar rate to IPNV, there is equal com- petition for cells and no difference is seen in the IPNVVHSV system. This hypothesis would be supported by the results with the EPC cells, in which the IPNV did not replicate and the IHNV titer was not affected. Further, elsewhere (Alonso et al. 1999a), we demonstrated a MOI-dependent inhibition of IHNV infection by IPNV; however, a 1000-fold reduction of IPNV was necessary to balance the IHNV replication, and it is probable that other factors contribute to the loss of infectivity. Competition between viruses for a common receptor may be one such factor.

Brudesth et al. (2002) characterized the interactions between IHNV and VHSV during the experimental coinfection of rainbow trout in terms of viral distribution, histopathological changes and the extent of viral replication in the kidney. They concluded that both viruses establish an infection and that double infection does not result in a significantly lower titer of any of the viruses in kidney. However, the distribution of IHNV in internal organs was more restricted, and was not found in the brain, suggesting competition for the same cell receptor on the target cells in brain tissue. These results agree in part with our observations on the IPNV-VHSV coinfection and with the earlier study of Wolf \& Vestergard-Jorgensen (1970) on RTG-2 cells: the viruses can infect cell cultures simultaneously, yielding similar infective titers but it seems that IPNV does not compete with VHSV for attachment sites; there are no data for IHNV, but in a previous work we demonstrated that the dominance of IPNV in dual infection with IHNV in BF-2 cells occurred even when IHNV infection began $24 \mathrm{~h}$ earlier (Alonso et al. 1999a).

There is another factor that could affect virus growth in dual infections: the production of interferons (IFN) and the establishment of an antiviral state by induction of antiviral proteins. IFN-like activity has been demonstrated in a number of fish species (Robersten 1998) and in several salmonid cell lines (Eaton 1990, Nygaard et al. 2000). Antiviral proteins are inducible by the double-stranded RNA (dsRNA) polyinosinic:polycytidylic acid (poly I:C), which is a well-known inducer of Type I IFN in higher vertebrates (Trobridge et al. 1997). Jensen et al. (2002b) demonstrated that CHSE214 (Chinook salmon embryo) cells are able to produce Type I IFN in the presence of transfection agents.

Herein we have shown that BF-2 cells transfected with the dsRNA poly I:C are able to induce secretion of components with characteristics of Type I IFN-like activity which exhibit differential protection against the viruses tested. While the IPNV infective titer was not reduced in the treated cells and VHSV was only slightly affected, the IHNV yield was reduced 200-fold. Considering that double-stranded RNA viruses are inducers of Type I IFN(s) (Dorson et al. 1992), IPNV 
might confer some protection and contribute to the loss of infectivity of IHNV in the coinfections. The role that innate immunity plays in protecting fish from virus infection is of great interest, but the interactions between viruses have yet to be investigated at this level. Our preliminary results (data not shown) suggest that in vitro induction of IFN-like activity is highly dependent on the cell cultures and the infection procedures selected, so comparative studies of several cell lines would be particularly interesting.

Previous reports by Chinchar et al. (1998) showed the ability of CCO cells to synthesize detectable levels of an interferon-like factor following infection with ultraviolet-inactivated catfish reovirus; this virus inhibits channel catfish herpesvirus replication by 2 different mechanisms - the induction of an antiviral factor and, as a result, the induction of its own replication. Similarly, Jensen et al. (2002a) studied the effect of interferon and poly I:C on the antiviral activity of SHK-1 and TO cells against infectious anemic salmon (ISA) virus and IPNV, and demonstrated that these viruses showed very different sensitivities to the antiviral activity of IFN in Atlantic salmon cells. Whereas IPNV infection was strongly inhibited in TO cells stimulated with poly I:C or AS-IFN, no inhibition of ISAV infection was observed.

In vivo, the state of partial resistance generated by a primary invader (IPNV) against a secondary infection with IHNV or VHSV was first described by de Kinkelin et al. (1992). Since then, other interesting approaches to viral interference mediated by interferon have been shown experimentally (Hedrick et al. 1994, LaPatra et al. 1995, Johansen \& Sommer 2001). More recently, Pakinking et al. (2004) have demonstrated the essential role of an aquabirnavirus (ABV) in limiting the proliferation of VHSV in flounder in ABV-VHSV dual infection, and have documented the ability of the ABV to induce the synthesis of a potent IFN-like substance that possesses antiviral activity against VHSV.

In all these studies, the challenge with the second virus was conducted some days after the primary infection. No data are available on antiviral states induced in simultaneous coinfections. Thus, in vitro and in vivo studies of the correlation between viral inhibition and the expression of antiviral proteins in IPNV-IHNV and IPNV-VHSV systems would be of interest and we are currently undertaking such work in rainbow trout and brown trout.

The results of viral interactions in piscine dual infections depend on the type of viruses involved and are important for sanitary control. While samples from hypothetical coinfections of IPNV-IHNV need to be assayed using sensitive methods (nested-PCR, neutralization of IPNV) to reveal the presence of the rhabdovirus, we have demonstrated here that both standard and molecular methods detect the VHSV in single and double infections. This observation is useful for diagnostic programs, since VHSV is a matter of concern for marine aquaculture: increasing outbreaks of the virus are being reported among marine fish (Mortensen et al. 1999, Meyers et al. 1992, Meyers \& Winton 1995) and the potential virulence of such strains has not yet been clearly determined.

More studies on viral coinfections are necessary, since they provide useful models for piscine virus studies either for practical purposes, such as the selection of optimal diagnostic methods for the accurate detection of all viruses present in a fish population, or for academic study, such as analyses of virus-virus and virus-cell interactions.

Acknowledgements. This study was supported by the Ministerio de Ciencia y Tecnologia (MCYT), grant AGL2001-1256. The excellent technical assistance of M. Sanchez and L. Guaita is appreciated.

\section{LITERATURE CITED}

Alonso M, Rodríguez S, Pérez-Prieto SI (1999a) Viral coinfection in salmonids: infectious pancreatic necrosis virus interferes with infectious hematopoietic necrosis virus. Arch Virol 144:657-673

Alonso M, Rodríguez S, Pérez-Prieto SI (1999b) Nested PCR improves detection of infectious hematopoietic necrosis virus in cells coinfected with infectious pancreatic necrosis virus. J Virol Methods 81:1-9

Alonso M, Rodriguez Saint-Jean S, Pérez-Prieto SI (2003) Virulence of infectious hematopoietic necrosis virus and infectious pancreatic necrosis virus coinfection in rainbow trout (Oncorhynchus mykiss) and nucleotide sequence analysis of the IHNV glycoprotein gene. Arch Virol 148: 1507-1521

Bruchhof B, Marquardt O, Enzman PJ (1995) Differential diagnosis of fish pathogenic rhabdoviruses by reverse transcriptase-dependent polymerase chain reaction. J Virol Methods 55:111-119

Brudesth BE, Castric J, Evensen O (2002) Studies on pathogenesis following single and double infections with viral hemorrhagic septicemia virus and infectious hematopoietic necrosis virus in rainbow trout (Oncorhynchus mykiss). Vet Pathol 39:180-189

Chinchar VG, Logue O, Antao A, Chinchar GD (1998) Channel catfish reovirus (CRV) inhibits replication of channel catfish herpesvirus (CCV) by two distinct mechanisms: viral interference and induction of an anti-viral factor. Dis Aquat Org 33:77-85

Chomczynski P, Sachi N (1987) Single-step method of RNA isolation by acid guanidinium thiocyanate-phenol chloroform extraction. Anal Biochem 162:156-159

de Kinkelin P, Dorson M, Renault T(1992) Interferon and viral interference in viruses of salmonid fish. In: Kimura T (ed) Proceedings of the OJI International symposium on salmonid diseases. Hokkaido University Press, Sapporo, p 241-249

Dorson M, de Kinkelin P, Torchy C (1992) Interferon synthesis in rainbow trout fry following infection with infectious pancreatic necrosis virus. Fish Shellfish Immunol 2:311-313 
Eaton WD (1990) Anti-viral activity in four species of salmonids following exposure to poly inosinic:cytidylic acid. Dis Aquat Org 9:193-198

Hedrick RP, LaPatra SE, Yun S, Lauda KA, Jones GR, Congleton JL, de Kinkelin P (1994) Induction of protection from infectious hematopoietic necrosis virus in rainbow trout Onchorhynchus mykiss by pre-exposure to the avirulent cutthroat trout virus (CTV). Dis Aquat Org 20:111-118

Hill BJ, Williams RF, Finlay J (1981) Preparation of antisera against fish virus disease agents. Dev Biol Stand 49: 209-218

Jensen I, Albuquerque A, Sommer A, Robertsen B (2002a) Effect of poly I: C on the expression of Mx proteins and resistance against infection by infectious salmon anaemia virus in Atlantic salmon. Fish Shellfish Immunol 13: 311-326

Jensen I, Larsen R, Robertsen B (2002b) An antiviral state induced in Chinook salmon embryo cells (CHSE-214) by transfection with the double-stranded RNA poly I:C. Fish Shellfish Immunol 13:367-378

Johansen LH, Sommer AI (2001) Infectious pancreatic necrosis virus infection in Atlantic salmon Salmo salar postsmolts affects the outcome of secondary infections with infectious salmon anaemia virus or Vibrio salmonicida. Dis Aquat Org 47:109-117

Kim CH, Dummer DM, Chiou PP, Leong JA (1999) Truncated particles produced in fish surviving infectious hematopoietic virus infection: mediators of persistence? J Virol 73:443-849

Koener JF, Passavant CW, Kurath G, Leong J (1987) Nucleotide sequence of a cDNA clone carrying the glycoprotein gene of infectious hematopoietic necrosis virus, a fish rhabdovirus. J Virol 61:1342-1349

LaPatra S (1996) The use of serological techniques for virus surveillance and certification of finfish. Annu Rev Fish Dis 6:15-28

LaPatra SE, Lauda KA, Woolley MJ, Armstrong R (1993) Detection of a naturally occurring coinfection of IHNV and IPNV in rainbow trout. Newsl Am Fish Soc Fish Health Sect 21:9-10

LaPatra SE, Lauda KA, Jones GR (1995) Aquareovirus interference mediated resistance to infectious hematopoietic necrosis virus. Vet Res 26:455-459

Melby HP, Falk K (1995) Study of the interaction between a persistent infectious pancreatic necrosis virus (IPNV) infection and experimental infectious samon anemia (ISA) in Atlantic salmon Salmo salar L. J Fish Dis 18:576-586

Meyers TR, Winton JR (1995) Viral hemorrhagic septicemia virus in North America. Annu Rev Fish Dis 5:3-24

Meyers TR, Sullivan J, Emmenegger E, Follet J, Short S, Batts WN, Winton JR (1992) Identification of viral hemorrhagic septicemia virus isolated from Pacific cod Gadus macrocephalus in Prince William Sound, Alaska, USA. Dis Aquat Org 12:167-175

Mortensen HF, Heur OE, Lorenzen N, Otte L, Olesen NJ (1999) Isolation of viral haemorrhagic septicaemia virus from marine fish species in the Baltic sea, Kattegat, Skagerrak and the North Sea. Virus Res 63:95-106

Mulcahy D, Fryer JL (1976) Double infection of rainbow trout fry with IHN and IPN viruses. Newsl Am Fish Soc Fish Health Sect 5:5-6

Nygaard R, Husgard S, Sommer A, Leong JA, Robertsen B (2000). Induction of Mx protein by interferon and doublestranded RNA in salmonid cells. Fish Shellfish Immunol 10:435-450

Editorial responsibility: Jo-Ann Leong, Kaneohe, Hawaii, USA
Pakingking R, Takano R, Nishizawa T, Mori K, Lida Y, Arimoto M, Muroga K (2003) Experimental coinfection with aquabirnavirus and viral hemorrhagic septicemia virus (VHSV), Edwardsiella tarda or Streptococcus iniae in Japanese flounder Paralichthys olivaceus. Fish Pathol 38:15-21

Pakingking R, Okinaka Y, Mori K, Arimoto M, Muroga K, Nakai T (2004) In vivo and in vitro analysis of the resistance against viral haemorrhagic virus in Japanese flounder (Paralichthys olivaceus) precedingly infected with aquabirnavirus. Fish Shellfish Immunol 17:1-11

Pérez SI, Rodríguez S, Vilas P (1994) Flow cytometry in fish virology. In: Stolen JS (ed) Techniques in fish immunology. SOS Publications, Fair Haven, NJ, p 161-173

Pryde A, Melvin WT, Munro ALS (1993) Nucleotide sequence analysis of the serotype-specific epitope of infectious pancreatic necrosis virus. Arch Virol 129:287-293

Reno PW (1999) Infectious pancreatic necrosis and associated aquatic birnaviruses. In: Woo PTK, Bruo DW (eds) Fish diseases and disorders, Vol 3. Viral, bacterial and fungal infections. CABI Publishing, New York

Robertsen B (1998) Immunology of fishes. Cytokines. In: Pastoret PP, Griebel P, Bazin H, Goaverts A (eds) Handbook of vertebrate immunology. Academic Press, London, p 11-13

Rodríguez S, Vilas MP, Alonso M, Pérez SI (1995) Study of a viral-dual infection in rainbow trout (Oncorhynchus mykiss) by seroneutralization, western blot and polymerase chain reaction assay. Microbiol SEM 11:461-470

Rodríguez S, Alonso M, Pérez-Prieto SI (2001) Detection of infections pancreatic necrosis virus (IPNV) from leukocytes of carrier rainbow trout Oncorhynchus mykiss. Fish Pathol 36:139-146

Rodriguez S, Borrego JJ, Pérez Prieto SI (2003) Infectious pancreatic necrosis virus: biology, pathogenesis and diagnostic methods. Adv Virus Res 62:113-165

Schlotfeldt HJ, Frost JW (1975) Doppelinfektion von Regenbogenforellen mit dem Virus der viralen hämorrhagischen Septikämie (VHS) und dem Virus der infectiosen Pankreasnekrose (IPN). Berl Münch Tierärztl Wochenschr 88: 455

Thiéry M, Lecocq-Xhonneux F, Dheur I, Renard A, de Kinkelin P (1991) Sequence of a cDNA carrying the glycoprotein gene adn part of the matrix protein 112 gene of viral haemorrhagic septicaemia virus, a fish rhabdovirus. Biochim Biophys Acta 1090:345-347

Trobridge GD, Chiou PP, Kim CH, Leong JA (1997) Induction of the Mx protein of rainbow trout Oncorhynchus mykiss in vitro and in vivo with poly I:C ds RNA and infectious hematopoietic necrosis virus. Dis Aquat Org 30:91-98

Vilas MP, Pérez S, Rodriguez S (1990) Obtención de sueros inmunes en conejo frente a antigenos de virus de salmónidos. In: Landin A, Ceriño A (eds) Actas del III Congreso Nacional de Acuicultura. Xunta de Galicia, p 837-842

Vilas MP, Rodriguez S, Pérez S (1994) A case of coinfection of IPN and IHN virus in farmed rainbow trout in Spain. Bull Eur Assoc Fish Pathol 14:1-4

Winton JR (1991) Recent advances in detection and control of infectious hematopoietic necrosis virus in aquaculture. Annu Rev Fish Dis 1:83-93

Wolf K (1988) Fish viruses and fish viral diseases. Cornell University Press, Ithaca, NY

Wolf K, Vestergard-Jorgensen PE (1970) Salmonid viruses: double infection of RTG-2 cells with Egtved and infectious pancreatic necrosis viruses. Arch Ges Virusforsch 29: $337-342$

Submitted: December 6, 2004; Accepted: July 8, 2005

Proofs received from author(s): November 8, 2005 